Research Paper

\title{
Benzyl-isothiocyanate Induces Apoptosis and Inhibits Migration and Invasion of Hepatocellular Carcinoma Cells in vitro
}

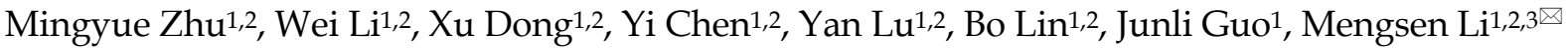 \\ 1. Hainan Provincial Key Laboratory of Carcinogenesis and Intervention, Hainan Medical College, Haikou 571199, Hainan Province, PR. China. \\ 2. Key Laboratory of Molecular Biology, Hainan Medical College, Haikou 571199, Hainan Province, PR. China. \\ 3. Institution of Tumor, Hainan Medical College, Haikou 570102, Hainan Province, PR. China. \\ $\triangle$ Corresponding author: Mengsen Li, Professor, Ph.D; Hainan Provincial Key Laboratory of Carcinogenesis and Intervention, Hainan Medical College, 3 \\ Xueyuan Road, Longhua District, Haikou 571199, Hainan Province, PR. China. Tel/Fax: +86-898-66895322; Email: mengsenli@163.com. \\ (C) Ivyspring International Publisher. This is an open access article distributed under the terms of the Creative Commons Attribution (CC BY-NC) license \\ (https://creativecommons.org/licenses/by-nc/4.0/). See http://ivyspring.com/terms for full terms and conditions.
}

Received: 2016.06.06; Accepted: 2016.10.29; Published: 2017.01.15

\begin{abstract}
Despite consideration of benzyl isothiocyanate(BITC) is applied to prevention and therapeutic of cancer, the role of BITC in inducing apoptosis, and inhibiting migration and invasion of hepatocellular carcinoma(HCC) cells is still unclear. In this study, we aim to explore the effects of $\mathrm{BITC}$ on the growth, migration and invasion of $\mathrm{HCC}$ cells in vitro. When human $\mathrm{HCC}$ cell lines, Bel 7402 and HLE, were treated with an optimal concentration of BITC for 48 hours, the results indicated that BITC inhibits growth and promotes apoptosis of HCC cells; BITC has a significant inhibitory effect on the migration and invasion of HCC cells. BITC stimulated expression of caspase-3/8 and PARP-1, and suppressed expression of survivin, MMP2/9 and CXCR4. BITC also inhibited the enzymatic activities of MMP2 and MMP9. Altogether, BITC was able to induce apoptosis and suppress the invasive and migratory abilities of Bel 7402 and HLE cells. The role mechanism of BITC might involve an up-regulating the expression of apoptosis-related proteins and down-regulating the expression of metastasis-related proteins. BITC may be applied as a novel chemotherapy for HCC patients.
\end{abstract}

Key words: Benzyl isothiocyanate (BITC), Hepatocellular carcinoma cells, Apoptosis, Metastasis.

\section{Introduction}

Hepatocellular carcinoma (HCC) is the sixth most common cancer and the third most common cause of cancer death[1,2]. Although an increasing number of new methods are now applied to treat HCC patients, surgery and chemotherapy are still the most important therapeutic approaches for HCC patients[3]. HCC cells are often refractory or resistant to standard chemotherapy and radiotherapy[4]. Drug resistance and tumor recurrence or metastasis are quite common in HCC patients, even in patients undergoing liver cancer resection or chemotherapy, and the survival ratio is only $30 \%$ to $40 \%$ at 5 years postoperatively [5]. Moreover, malignant behaviors, such as drug resistance and metastasis, often lead to poor prognoses for HCC patients.
The preventive effects of cruciferous vegetables, such as broccoli, cabbage, and cauliflower, against cancer have been suggested to be owing to their relatively high composition of glucosinolates, which release biologically active isothiocyanates (ITCs) [6,7], ITCs play important roles in the detoxification of carcinogens $[8,9]$. Benzyl isothiocyanate (BITC) is a member of the ITC family, and it is formed from the hydrolysis of glucotropaeolin in cruciferous vegetables. Many studies have reported that BITC prevents cancers in laboratory animals and might also be chemoprotective in humans because BITC has displayed anti-tumor activities in many types of cancer, including breast cancer[10,11], prostate cancer[12], and HCC $[13,14]$. These data indicated that 
BITC can be applied to prevent and treat cancer. Recently, we reported that BITC plays a role in inhibiting the growth of HCC cells through arresting cell cycle[15]. These results suggested that BITC is able to suppress the malignant behaviors of HCC cells. However, whether BITC plays a role in inducing apoptosis and inhibiting the migration and invasion of HCC cells is still unclear. In the present study, we found that BITC promotes apoptosis and suppresses the migration and invasion of HCC cells via regulating the expression of apoptosis- and metastasis-related proteins. This study provides an evidence for the potential application of BITC as an adjuvant treatment to inhibit metastasis and enhance chemotherapy. BITC is a novel nutrient for the prevention and treatment of HCC.

\section{Material and methods}

\section{Cell culture}

In this study, we selected the human HCC cell lines Bel 7402 (AFP-producer) and HLE (non-AFP-producer) for testing. These cells were the gifts from the Department of Cell Biology, Peking University Health Science Center (Beijing, China), and the cells were cultured with RPMI-160 medium supplemented with $10 \%$ heat-inactivated fetal calf serum (FCS) and were incubated at $37^{\circ} \mathrm{C}$ in a humidified atmosphere containing $5 \% \quad \mathrm{CO}_{2}$ as described[16].

\section{Cell growth detection by MTT methods}

A total of $1.5 \times 10^{4}$ Bel 7402 cells or HLE cells were plated in each well of 96-well plates and cultured in RPMI-1640 medium supplemented with $10 \%$ FCS at $37^{\circ} \mathrm{C}$ in a humidified atmosphere of $5 \%$ $\mathrm{CO}_{2}$ for $48 \mathrm{~h}$. The cells were cultured with medium not containing FCS for another $24 \mathrm{~h}$ and treated with different concentrations of BITC $(10-80 \mu \mathrm{mol} / \mathrm{L})$ for 48 h. The effects of BITC(Sigma-Aldrich Company Ltd, St. Louis, MO,UAS) treatment on cells growth were measured by a methylthiazolyldiphenyl-tetrazolium bromide(MTT) assay as previously described[17]. The growth ratio was calculated using the following formula: growth ratio=(control group $A_{490}$-treated group $\left.A_{490}\right)$ / control group $A_{490} \times 100 \%$

\section{Cell morphology was observed by microscopy and nuclear staining with DAPI}

To observe alterations in cellular morphology induced by BITC, Bel 7402 cells or HLE cells were plated at a density of $2.0 \times 10^{4} / \mathrm{ml}$ in 24 -well plates. The cells were treated with $40 \mu \mathrm{mol} / \mathrm{L}$ or $80 \mu \mathrm{mol} / \mathrm{L}$ BITC. After treatment for $48 \mathrm{~h}$, cellular morphology was observed under light microscopy, and the cells were stained with 4,6-diamidino-2-phenylindole
dihydrochloride(DAPI) solution. The cells were imaged using a fluorescence microscope at $100 \times$ magnification. In this study, nuclear pyknosis and fragmentation were taken to define apoptosis, and these criteria were evaluated by fluorescence microscopy as previously described $[18,19]$.

\section{Flow cytometry was used to analyze apoptosis}

Bel 7402 cells and HLE cells were cultured in RPMI-1640 medium supplemented with 10\% FCS at $37^{\circ} \mathrm{C}$ in a humidified atmosphere and $5 \% \mathrm{CO}_{2}$. The cells were treated with BITC $(40 \mu \mathrm{mol} / \mathrm{L}$ or 80 $\mu \mathrm{mol} / \mathrm{L}$ ) for $48 \mathrm{~h}$, and the extent of apoptosis in Bel 7402 cells or HLE cells was analyzed by flow cytometry as previously described[19].

\section{Cell migration and invasion were detected by the Transwellmethod}

Cell migration and invasion assays were carried out according to the manufacturer's protocols and as previously described[20]. To measure cell migration, transwell chambers were used to observe cultured cell inserts (Transwell chamber; 8-mm pore size; Costar, High Wycombe, UK). Bel 7402 cells and HLE cells $\left(5 \times 10^{4}\right)$ were added to the upper chambers and cultured with serum-free RPMI-1640 medium and treated with BITC $(40 \mu \mathrm{mol} / \mathrm{L}$ or $80 \mu \mathrm{mol} / \mathrm{L})$ for $48 \mathrm{~h}$, whereas the lower chamber was filled with complete medium containing $20 \%$ FCS. After 48 h of incubation, the cells in the upper chamber were carefully removed with a cotton swab, and those that had migrated through the membrane to the lower surface were fixed with $90 \%$ methanol and stained with $0.1 \%$ crystal violet. The number of cells that had migrated through the pores was quantified by counting five independent visual fields using a microscope (Olympus) with a $20 \times$ objective. For invasion assays, transwell chambers were covered with Matrigel (BD Falcon, USA), and the experimental procedure was similar to that for the migration assays. The migratory cell or invasive cell ratio=(numbers of untreated groups-numbers of treated groups)/ numbers of untreated groups.

\section{Gelatin zymography assays for MMP2 and MMP9 activities}

Bel 7402 cells and HLE cells were treated with BITC $(40 \mu \mathrm{mol} / \mathrm{L}$ or $80 \mu \mathrm{mol} / \mathrm{L})$ for $48 \mathrm{~h}$, and MMP-2/9 protease activities in the concentrated supernatants of Bel 7402 cells or HLE cells were detected by gelatin zymography. Briefly, SDS-PAGE under non-reducing conditions was completed using gels containing $1 \%$ gelatin (Mini-PROTEAN II system; Bio-Rad), and electrophoresis was carried out at $4^{\circ} \mathrm{C}$. After washing with $2 \%$ Triton X-100 to remove the 
SDS, the gels were incubated at $37^{\circ} \mathrm{C}$ with buffer containing $50 \mathrm{mM}$ Tris ( $\mathrm{pH} 7.5), 5 \mathrm{mmol} / \mathrm{CaCl}_{2}$ and 1 $\mathrm{mmol} / 1 \mathrm{ZnCl}_{2}$ for $18 \mathrm{~h}$. MMP2/9 activities were visualized by staining with Coomassie Blue R-250(Bio-Rad) as previously described [21].

\section{Western blotting analysis}

To estimate the influence of BITC on the expression of apoptosis-related proteins and metastasis-related proteins, Bel 7402 cells and HLE cells were treated with BITC $(40 \mu \mathrm{mol} / \mathrm{L}$ or 80 $\mu \mathrm{mol} / \mathrm{L})$ for $48 \mathrm{~h}$, and the expression of apoptosis-related proteins, such as actived-caspase-3, actived-caspase-8, PARP-1 and survivin, and metastasis-related proteins, such as MMP2, MMP9 and CXCR4, in Bel 7402 cells or in HLE cells was analyzed by Western blotting as previously described[17].

\section{Statistical analysis}

The data are presented as the mean \pm S.D. The statistical analysis was performed using Student's $t$ test (for two experimental groups). The significance was set at $P<0.05$. Statistical significance was determined using Student's t-test and $F$ test (SPSS 11.5 software for Windows, SPSS Inc., Chicago, IL, US).

\section{Results}

\section{BITC inhibited the growth and induced apoptosis of HCC cells in vitro}

In the present study, we used the MTT method to detect the effects of BITC on the growth of the human HCC cell lines, Bel 7402 and HLE. The results indicated that BITC inhibited the growth of HCC cells in a dose-dependent manner. When Bel 7402 cells and HLE cells were treated with different concentrations (10-80 $\mu \mathrm{mol} / \mathrm{L})$ of BITC for $48 \mathrm{~h}$, the proliferation ratio of Bel 7402 cells and HLE cells were significantly inhibited, whereas at a concentration $>40 \mu \mathrm{mol} / \mathrm{L}$ BITC, the proliferation inhibited ratio were $28.6 \%$ (40 $\mu \mathrm{mol} / \mathrm{L}$ of BITC) and $46.6 \%(80 \mu \mathrm{mol} / \mathrm{L}$ of BITC) in Bel 7402 cells (Figure 1A). Similarly, when HLE cells were treated with different concentrations $(10-80 \mu \mathrm{mol} / \mathrm{L})$ of BITC for $48 \mathrm{~h}$, the cellular growth was significantly inhibited at concentrations $>20$ $\mu \mathrm{mol} / \mathrm{L}$ BITC, and the growth inhibited ratio was $19.2 \%-62.4 \%$ (Figure 1A). To further prove that BITC inhibits the growth of HCC cells, we performed morphological analyses. Figures $1 \mathrm{~B}$ and $1 \mathrm{C}$ show the cells morphological change in Bel 7402 cells and HLE cells when treated with concentrations of $40 \mu \mathrm{mol} / \mathrm{L}$ or $80 \mu \mathrm{mol} / \mathrm{L}$ BITC for $48 \mathrm{~h}$. Apoptosis-related morphology changes in Bel 7402 cells and HLE cells were observed under light and fluorescent microscopy using DAPI staining, where the numbers of cells with cellular nuclear condensation and pyknosis were significantly increased. In addition, the morphological characteristics of apoptosis, including apoptosome formation and nuclear shrinkage, were apparent in the BITC-treated Bel 7402 cells and HLE cells. The flow cytometric analysis demonstrated that when Bel 7402 cells and HLE cells were treated with BITC $(40 \mu \mathrm{mol} / \mathrm{L}$ or $80 \mu \mathrm{mol} / \mathrm{L})$ for $48 \mathrm{~h}$, the apoptosis ratio of the cells significantly increased (Figure 2). These results demonstrated that BITC was able to induce apoptosome occurrence and promote apoptosis in Bel 7402 cells and HLE cells.

\section{BITC promotes expression of actived-caspase-3/8 and PARP-1 and suppressed expression of survivin in HCC cells}

To explore the role of BITC in the expression of apoptosis-related proteins in the present study, we evaluated the expression of caspase-3/8, PARP-1 and survivin. Western blotting analysis indicated that expression of actived-caspase- $3 / 8$ and PARP- 1 were significantly increased, but the expression of survivin was significantly restrained in Bel 7402 cells (Figure 3A). To our surprise, the expression of actived-caspase-3 did not change much, but the expression of actived-caspase-8 and PARP-1 was significantly enhanced, and the expression of survivin was significantly suppressed in HLE cells (Figure 3B). These results indicated that BITC could inhibit expression of survivin and stimulate the expression of actived-caspase-8 and PARP-1 in HCC cells. However, to influence on the expression of actived-caspase-3, BITC was able to promote its expression in Bel 7402 cells but had little effect on HLE cells.

\section{BITC inhibits the invasion and migration of HCC cells}

To evaluate the influence of BITC on regulating invasion and migration in Bel 7402 cells and HLE cells, transwell chamber migration assays were used, and the results demonstrated that the ratio of migratory and invasive Bel 7402 cells and HLE cells were significantly decreased following treatment with BITC $(40 \mu \mathrm{mol} / \mathrm{L}$ or $80 \mu \mathrm{mol} / \mathrm{L})$ for $48 \mathrm{~h}$. When the cells were treated with $40 \mu \mathrm{mol} / \mathrm{L}$ BITC, the invasive ratios of Bel 7402 cells and HLE cells were $64.2 \pm 4.3 \%$ and $52.4 \pm 5.3 \%$, respectively, compared with the control group. When the cells were treated with 80 $\mu \mathrm{mol} / \mathrm{L}$ BITC, the invasive ratios of Bel 7402 cells and HLE cells were $54.6 \pm 4.0 \%$ and $36.7 \pm 5.4 \%$, respectively, compared with the control group (Figure $4 \mathrm{~A}$ ). When the cells were treated with $40 \mu \mathrm{mol} / \mathrm{L}$ BITC, the migratory ratios of Bel 7402 cells and HLE cells were 
$62.3 \pm 2.9 \%$ and $39.7 \pm 4.6 \%$, respectively, compared with the control group. When the cells were treated with $80 \mu \mathrm{mol} / \mathrm{L}$ BITC, the migratory ratios of Bel 7402 cells and HLE cells were $51.4 \pm 3.1 \%$ and $19.8 \pm 3.3 \%$, respectively, compared with the control group (Figure 4B). These results demonstrated that BITC was able to inhibit invasion and migration of HCC cells in vitro.

A

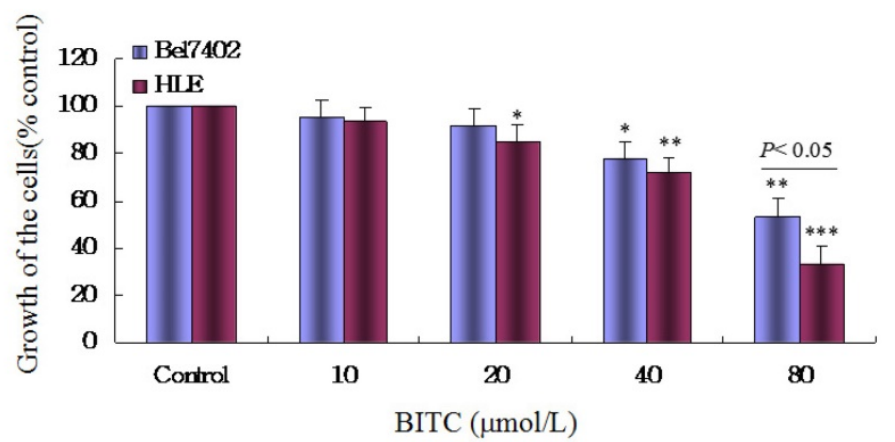

B
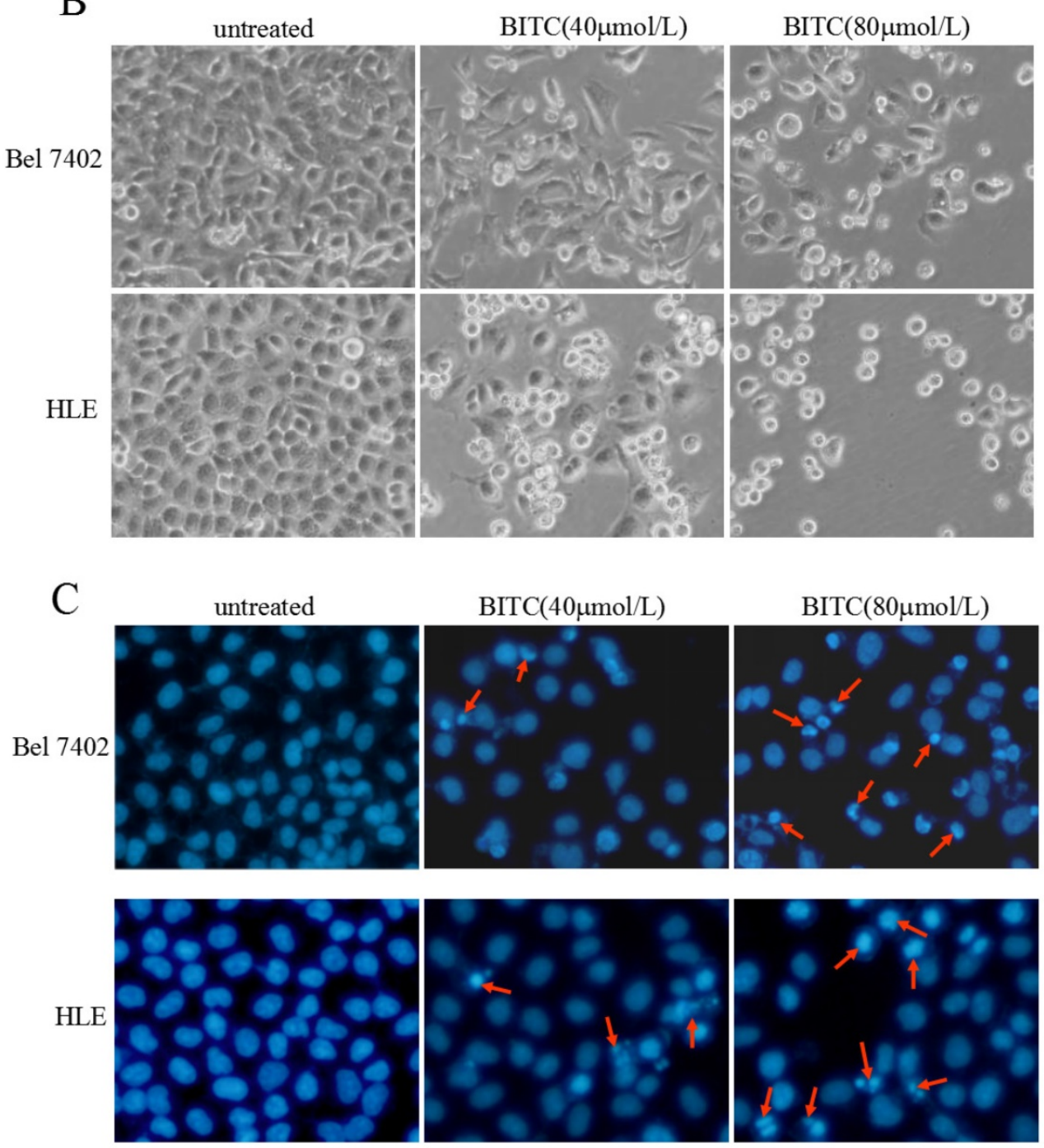

Figure 1. Influence of BITC on the growth and apoptosis of Bel $\mathbf{7 4 0 2}$ cells and HLE cells. A, Bel 7402 cells or HLE cells were treated with different concentrations $(10-80 \mu \mathrm{mol} / \mathrm{L})$ of BITC for $48 \mathrm{~h}$, and the MTT method was applied to detect the growth of the cells; $* P<0.05$, $* * P<0.01$, and $* * * P<0.01$ vs. control groups. B and C, Bel 7402 cells or HLE cells were treated with BITC ( $40 \mu \mathrm{mol} / \mathrm{L}$ and $80 \mu \mathrm{mol} / \mathrm{L})$ for $48 \mathrm{~h}$, and the growth morphology of Bel 7402 cells or HLE cells was observed by microscope. The cytoblasts of Bel 7402 cells and HLE cells were stained with DAPI and observed by fluorescent microscopy. The red arrows indicate apoptosomes. The images are representation of at least three independent experiments. 

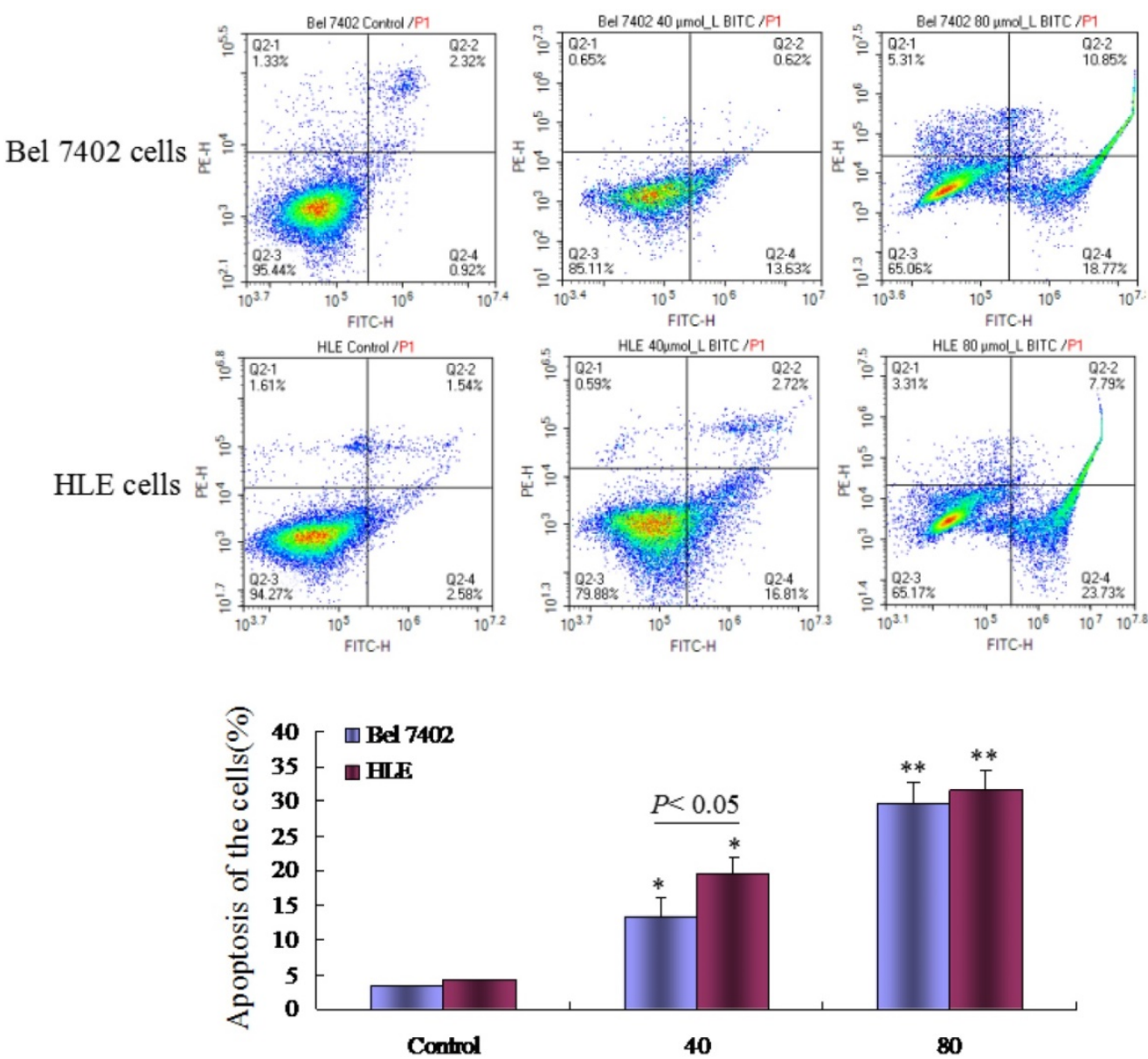

$\operatorname{BITC}(\mu \mathrm{mol} / \mathrm{L})$

Figure 2. Effects of BITC on the apoptosis of Bel 7402 cells and HLE cells. A, Bel 7402 cells and HLE cells were treated with $40 \mu \mathrm{mol} / \mathrm{L}$ and $80 \mu \mathrm{mol} / \mathrm{L}$ of BITC for $48 \mathrm{~h}$, and the apoptosis of Bel 7402 cells and HLE cells was analyzed by flow cytometry. The bottom column picture shows the statistical analysis of the apoptosis ratios; $* P<0.05, * * P<0.01$ vs. control groups. The images are representation of at least three independent experiments.
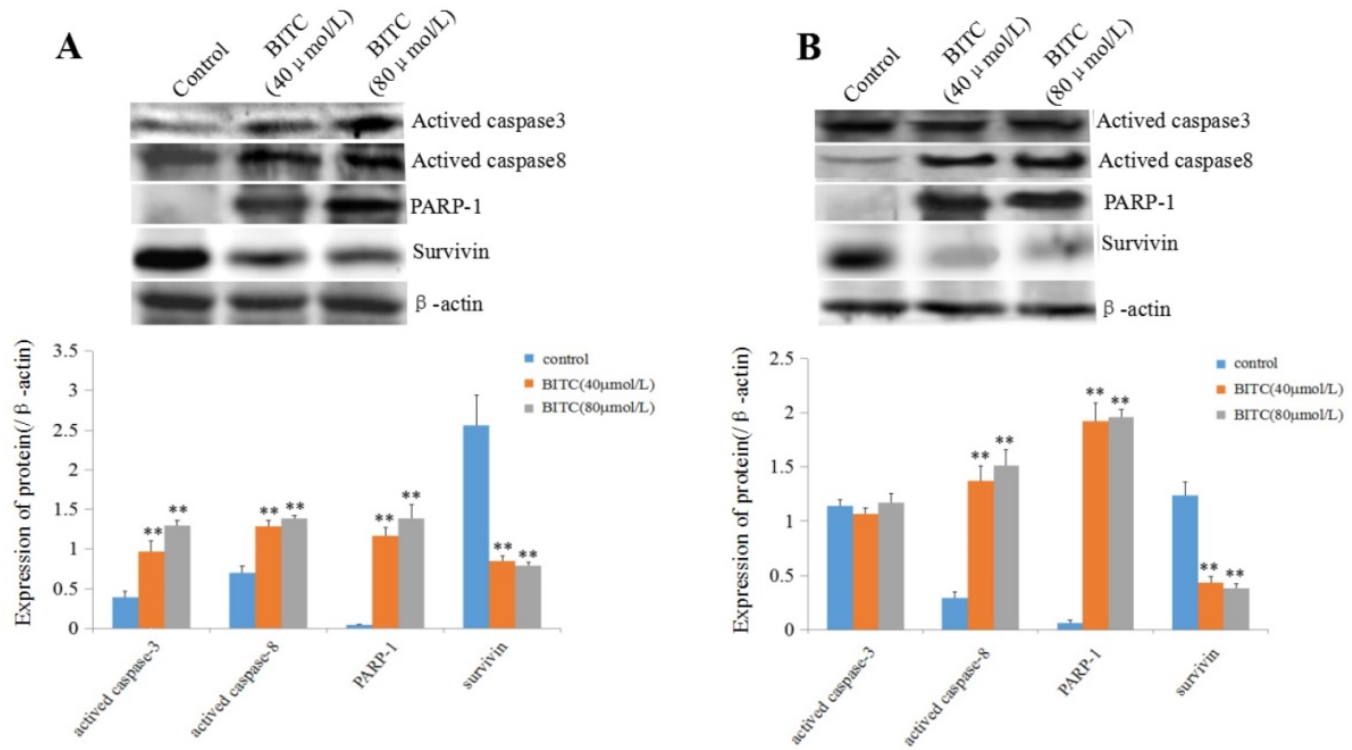

Figure 3. Effects of BITC on the expression of apoptosis-related proteins in Bel 7402 cells and HLE cells. A and B, Bel 7402 cells or HLE cells were treated with $40 \mu \mathrm{mol} / \mathrm{L}$ or $80 \mu \mathrm{mol} / \mathrm{L}$ of BITC for $48 \mathrm{~h}$, and the expression of actived-caspase-3, actived-caspase-8, PARP-1 and survivin in the cells was evaluated by Western blotting. The bottom column picture indicates the statistical analysis of the expression of the proteins ratios (compared with the internal control $\beta$-actin), $* * P<0.01$, vs. control groups. The images are representation of at least three independent experiments. 
A
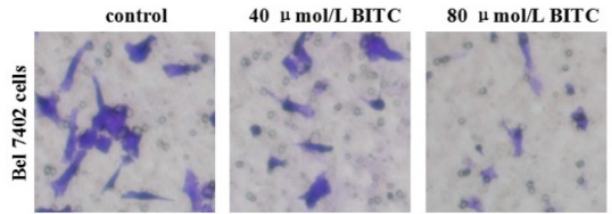

control $40 \mu \mathrm{mol} / \mathrm{L} \mathrm{BITC}$

$80 \mu \mathrm{mol} / \mathrm{L} \mathrm{BITC}$
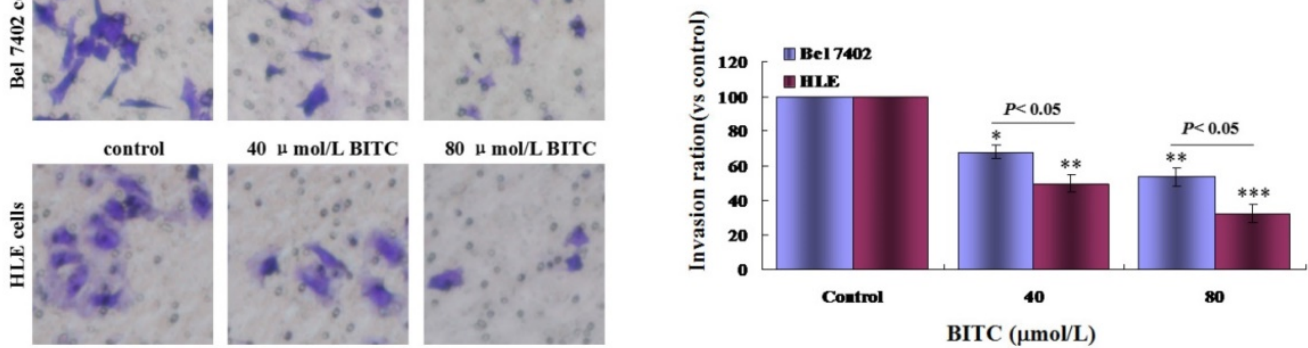

B

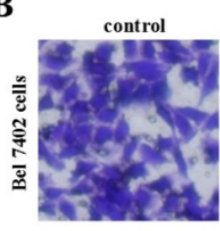

$40 \mu \mathrm{mol} / \mathrm{L}$ BITC
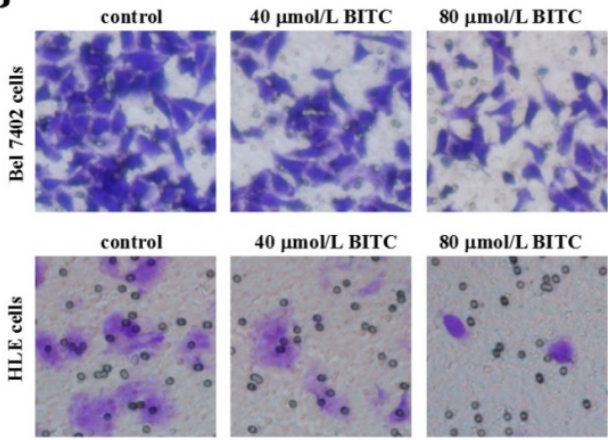

$40 \mu \mathrm{mol} / \mathrm{L}$ BITC
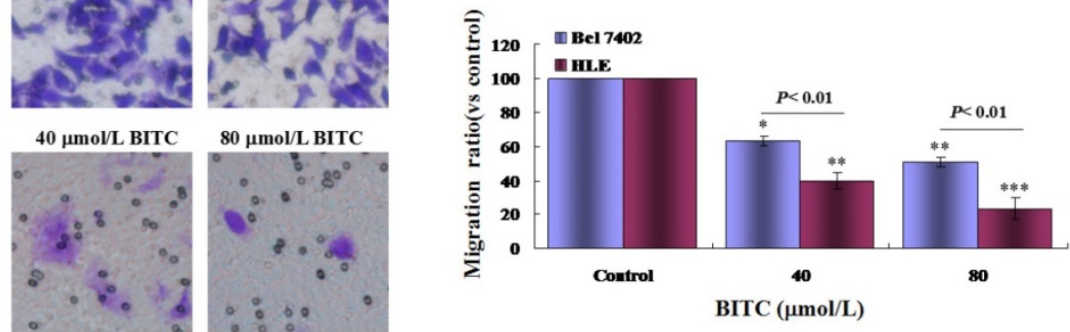

Figure 4. Influence of BITC on the migration and invasion of Bel 7402 cells and HLE cells. A and B, Bel 7402 cells or HLE cells were treated with 40 $\mu \mathrm{mol} / \mathrm{L}$ or $80 \mu \mathrm{mol} / \mathrm{L}$ of BITC for $48 \mathrm{~h}$, and the invasion $(\mathrm{A})$ and migration (B) of Bel 7402 cells and HLE cells were detected by transwell chamber. The right column picture indicated the statistical analysis of the numbers of the migratory and invasive cells; $* P<0.05$, $* * P<0.01$, and $* * * P<0.001$ vs. control groups. The images were representation of at least three independent experiments.

BITC inhibits the expression of MMP2, MMP9, CXCR4 and the activities of MMP2/9

To explore the role of BITC in the expression of metastasis-related proteins, and the activities of MMP2/9, we evaluated the expression of MMP2/9 and CXCR4. Western blotting analyses indicated that expression of MMP2/9 and CXCR4 were significantly suppressed compared with that of the control (Figure $5 \mathrm{~A}-\mathrm{C}$ ), and the activities of MMP2/9 were also significantly restrained in Bel 7402 cells and HLE cells treated with BITC $(40 \mu \mathrm{mol} / \mathrm{L}$ or $80 \mu \mathrm{mol} / \mathrm{L})$ for $48 \mathrm{~h}$ (Figure 5D). These results revealed that BITC was able to inhibit expression of MMP2/9 and CXCR4 and the activity of MMP2/9 in HCC cells.

\section{Discussion}

Chemotherapy is critical for the treatment of cancer, as chemo-drugs have a therapeutic effect by inducing the apoptosis of cancer cells. Apoptosis plays important roles in developmental processes, maintenance of homeostasis, and elimination of seriously damaged cells. Apoptosis obstacle could stimulate carcinogenesis, and drugs inducing apoptosis of cancer cells can inhibit the growth of cancer cells as well as suppress the metastasis of cancer cells. Proliferation and metastasis are important traits of cancer cells, and targeting apoptosis and metastasis is a valid approach to develop novel anticancer drugs. Many ITCs, including BITC, are effective chemoprotective agents against chemical carcinogenesis in experimental animals. Studies have found that BITC was able to induce apoptosis in many cancer cells via cell cycle arrest and stimulation of caspases signaling pathways[22-25] and suppression of invasion and angiogenesis of glioma cells[26], breast cancer cells[27], head and neck squamous cell carcinoma[28], and non-small cell lung cancer cells[29]. These results revealed that BITC can induce apoptosis and inhibit metastasis in many types of cancer. Although BITC has an inhibitory effect on diethylnitrosamineinduced hepatocarcinogenesis in rats, whether BITC is able to induce apoptosis and metastasis in HCC cells is still unclear. In the present study, we reported that BITC could directly suppress the growth and promote the apoptosis of HCC cells, and it could also play a role in inhibiting the metastasis of HCC cells in vitro. 
A

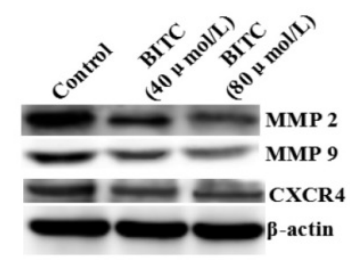

B

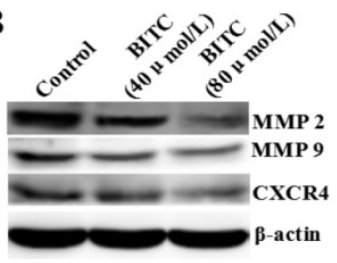

C

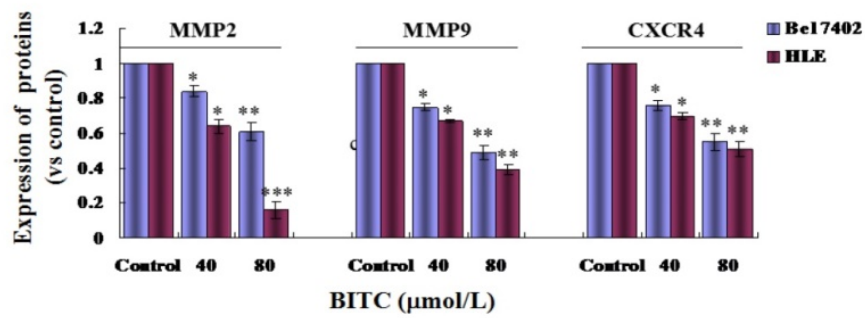

D

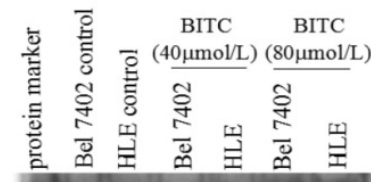

MMP2

MMP9

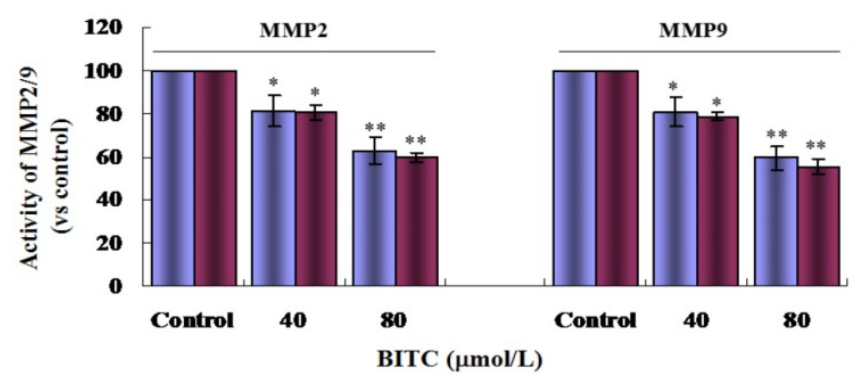

Figure 5. Influence of BITC on the expression of MMP2/9 and CXCR4 and the activity of MMP2/9 in Bel 7402 cells and HLE cells. A and B, Bel 7402 cells or HLE cells were treated with $40 \mu \mathrm{mol} / \mathrm{L}$ and $80 \mu \mathrm{mol} / \mathrm{L}$ of BITC for $48 \mathrm{~h}$, and the expression of MMP2, MMP9 and CXCR4 in the cells was evaluated by Western blotting. C, The column picture comprises the statistical analysis of the expression of the proteins ratio (compared with the internal control $\beta$-actin), $* P<0.05$, $* * P<0.01$ vs. control groups. D, Bel 7402 cells and HLE cells were treated with $40 \mu \mathrm{mol} / \mathrm{L}$ and $80 \mu \mathrm{mol} / \mathrm{L}$ of BITC for $48 \mathrm{~h}$ and the activity changes of MMP2/9 were detected by SDS-PAGE electrophoresis. The activities of MMP2/9 were analyzed by enzymatic reaction reagent kit, and the bottom column picture is the statistical analysis of the activities of the MMP2/9; $* P<0.05, * * P<0.01$ vs. control groups. The images are representation of at least three independent experiments.

A significant amount of evidence has revealed that BITC induced apoptosis by activating apoptosis-related signaling pathways or inhibiting growth signal pathways[25,30,31] and regulating the expression of apoptosis-related genes[32]. In this study, we found that BITC might stimulate the expression of activated-caspase-3/8 and PARP-1 and suppress the expression of survivin in Bel 7402 cells and in HLE cells. To our surprise, BITC had little influence on the expression of activated-caspase- 3 on HLE cells. Activated-caspase-3 plays a pivotal role in the promotion of apoptosis in cancer cells. Although some evidence has shown that BITC promotes apoptosis within the complicated signaling system[33], we speculate that BITC induces apoptosis of different HCC cells maybe through several apoptotic signaling pathways. Recently, we have reported that alpha fetoprotein(AFP) plays an antagonistic role of BITC via arresting cell cycle in liver cancer cells[15], and AFP could antagonize the apoptosis induced by paclitaxel[34], AFP also promotes malignant behaviors of HCC cells, including drug-resistance[20,36]. Because AFP is specifically expressed in HCC cells, in this study, we found that in HLE cells, a non-AFP-producer, cell growth was significantly inhibited by BITC at a concentration of $20 \mu \mathrm{mol} / \mathrm{L}$, but to Bel 7402 cells, an AFP-producer, the effect of BITC was emerged in 
concentration of $40 \mu \mathrm{mol} / \mathrm{L}($ Figure $1 \mathrm{~A})$, and we have found that AFP antagonized BITC suppressed apoptosis of HCC cells (data not shown). These data indicated that AFP expression in HCC cells was able to act against the effect of BITC in the treatment of HCC cells. These results indicated that HCC cells harbor a heterogeneity trait and provide important information about target selection for HCC patient therapy.

The metastasis of cancer cells involves expression changes of MMP2, MMP9 and CXCR4. A high expression of MMP2/9 concomitant with the activity is enhanced. The MMP2/9 enzymes can dissolve the surrounding tissue, leading to cancer cells invasion and migration away from the primary focus. CXCR4 is a receptor for stromal cell-derived factor-1alpha (SDF-1a), which stimulates migration of the cancer cells. Researchers have found that BITC inhibited invasion of glioma via suppressing the expression and activity of MMP2/9[26,36], and ITCs prevent the development of prostate adenocarcinoma via restraining the expression of CXCR4[37]. Although BITC plays a role in inhibiting the expression of MMP2/9 and CXCR4 and the activity of MMP2/9 in many cancer cells, including HCC cells[38], the mechanism by which BITC suppresses the metastasis of HCC cells is still unknown. In the present study, we report for the first time that BITC directly suppressed the expression of MMP2/9, CXCR4 and the activity of MMP2/9. These results indicated that BITC could induce apoptosis and restrain the metastasis of HCC cells through suppressing apoptosis signaling pathways and down-regulating expression of metastasis-related proteins, which promote the invasion and migration of HCC cells.

Altogether, this is the first time to report that BITC harbors a function to promote apoptosis and inhibit migration and invasion of HCC cells in vitro. BITC may be used as a novel nutrient compound for chemoprevention and therapy for HCC.

\section{Acknowledgments}

This work was supported by the National Natural Science Foundation of China (Nos. 81660463, 81560450, 31560243, 81360307 and 81260306); The Project of the Hainan Province Innovative Team (No. 2016CXTD008); The Natural Science Foundation of Hainan Province (Nos. 310044, 814293 and 20168263); The Fund for Hainan Provincial Society Development (No. 2015SF03); The Hainan Provincial Association for Science and the Technology Program of Youth Science Talent and Academic Innovation (No.201514) and grants from the Haikou Bureau of Industry \&
Information (No. Hnkyzx2014-07) and the Haikou Key Program of Science Technology (No. 2014062).

\section{Competing interests}

The authors who have taken part in this study declare that they have no competing interests.

\section{References}

1. Ferlay J, Shin HR, Bray F, Forman D, Mathers C, Parkin DM. Estimates of worldwide burden of cancer in 2008: GLOBOCAN 2008. Int J Cancer. 2010; 127: 2893-7.

2. Jemal A, Bray F, Center MM, Ferlay J, Ward E, Forman D: Global cancer statistics. CA Cancer J Clin. 2011; 61:69-90.

3. Bruix J, Sherman M. Management of hepatocellular carcinoma. Hepatology. 2005; 42:1208-36.

4. Hoshida Y, Fuchs BC and Tanabe KK. Prevention of hepatocellular carcinoma: potential targets, experimental models, and clinical challenges. Current Cancer Drug Targets. 2012; 12: 1129-59.

5. Altekruse SF, McGlynn KA and Reichman ME. Hepatocellular carcinoma incidence, mortality, and survival trends in the United States from 1975 to 2005. J Clin Oncol. 2009; 27: 1485-91.

6. Wattenberg LW. Inhibition of carcinogen-induced neoplasia by sodium cyanate, tert-butyl isocyanate, and benzyl isothiocyanate administered subsequent to carcinogen exposure. Cancer Res. 1981; 41:2991-4.

7. Wattenberg LW. Inhibitory effects of benzyl isothiocyanate administered shortly before diethylnitrosamine or benzo[a]pyrene on pulmonary and forestomach neoplasia in A/J mice. Carcinogenesis. 1987;8:1971-3.

8. Morse MA, $\mathrm{Zu} \mathrm{H}$, Galati AJ Schmidt CJ, Stoner GD. Dose-related inhibition by dietary phenethyl isothiocyanate of esophageal tumorigenesis and DNA methylation induced by N-nitrosomethylbenzylamine in rats. Cancer Lett. 1993;72:103-10.

9. Stoner GD, Morrissey DT, Heur YH, Daniel EM, Galati AJ, Wagner SA. Inhibitory effects of phenethyl isothiocyanate on $\mathrm{N}$-nitrosobenzylmethylamine carcinogenesis in the rat esophagus. Cancer Res. 1991;51:2063-8.

10. Hecht SS. Chemoprevention by isothiocyanates. J Cell Biochem Suppl. 1995; 22:195-209.

11. Guo Z, Smith TJ, Wang E, Eklind KI, Chung FL, Yang CS. Structure-activity relationships of arylalkyl isothiocyanates for the inhibition of 4-(methylnitrosam ino)-1-(3-pyridyl)-1-butanone metabolism and the modulation of xenobiotic- metabolizing enzymes in rats and mice. Carcinogenesis. 1993; 14:1167-73.

12. Talalay P, De Long MJ, Prochaska HJ. Identification of a common chemical signal regulating the induction of enzymes that protect against chemical carcinogenesis. Proc Natl Acad Sci U S A. 1988; 85:8261-5.

13. Herz C, Hertrampf A, Zimmermann S, Stetter N, Wagner M, Kleinhans C, et al. The isothiocyanate erucin abrogates telomerase in hepatocellular carcinoma cells in vitro and in an orthotopic xenograft tumour model of HCC. J Cell Mol Med. 2014;18:2393-403.

14. Yamaguchi H, Kidachi $Y$, Kamiie K, Noshita T, Umetsu H, Fuke Y, et al. Utilization of 6-(methylsulfinyl)hexyl isothiocyanate for sensitization of tumor cells to antitumor agents in combination therapies. Biochem Pharmacol. 2013; 86: 458-68

15. Zhu M, Li W, Dong X, Zhou P, Guo J, Li M. Alpha fetoprotein plays antagonistic role in benzyl-isothiocyanate arresting cell cycle in liver cancer cells. Chemotherapy: Open Access. 2016; 5: 195.

16. Li MS, Li PF, Yang FY, He SP, Du GG, Li G. The intracellular mechanism of alpha-fetoprotein promoting the proliferation of NIH 3 T3 cells. Cell Res. 2002; 12:151-6.

17. Li MS, Li PF, He SP, Du GG, Li G. The promoting molecular mechanism of alpha-fetoprotein on the growth of human hepatoma Bel7402 cell line. World J Gastroenterol. 2002; 8:469-75.

18. Li M, Zhou S, Liu X, Li P, McNutt MA, Li G. Alpha-Fetoprotein shields hepatocellular carcinoma cells from apoptosis induced by tumor necrosis factor-related apoptosis-inducing ligand. Cancer Lett. 2007; 249:227-34.

19. Li M, Li H, Li C, Guo L, Liu H, Zhou S, et al. Cytoplasmic alpha-fetoprotein functions as a co-repressor in RA-RAR signaling to promote the growth of human hepatoma Bel 7402 cells. Cancer Lett. 2009; 285:190-9.

20. Lu Y, Zhu M, Li W, Lin B, Dong X, Chen Y, et al. Alpha fetoprotein plays a critical role in promoting metastasis of hepatocellular carcinoma cells. J Cell Mol Med. 2016; 20: 549-58.

21. Guo J, Jie W, Shen Z, Li M, Lan Y, Kong Y, et al. SCF increases cardiac stem cell migration through PI3K/AKT and MMP-2/-9 signaling. Int J Mol Med. 2014; 34:112-8.

22. Tang NY, Chueh FS, Yu CC, Liao CL, Lin JJ, Hsia TC, et al. Benzyl isothiocyanate alters the gene expression with cell cycle regulation and cell death in human brain glioblastoma GBM 8401 cells. Oncol Rep. 2016; 35:2089-96. 
23. Sehrawat A, Singh SV. Short-form RON overexpression augments benzyl isothiocyanate-induced apoptosis in human breast cancer cells. Mol Carcinog. 2016; 55:473-85.

24. Wu CL, Huang AC, Yang JS, Liao CL, Lu HF, Chou ST, et al. Benzyl isothiocyanate (BITC) and phenethyl isothiocyanate (PEITC)-mediated generation of reactive oxygen species causes cell cycle arrest and induces apoptosis via activation of caspase-3, mitochondria dysfunction and nitric oxide (NO) in human osteogenic sarcoma U-2 OS cells. J Orthop Res. 2011; 29:1199-209.

25. Basu A, Haldar S. Dietary isothiocyanate mediated apoptosis of human cancer cells is associated with Bcl-xL phosphorylation. Int J Oncol. 2008; 33:657-63.

26. Zhu Y, Zhang L, Zhang GD, Wang HO, Liu MY, Jiang Y, et al. Potential mechanisms of benzyl isothiocyanate suppression of invasion and angiogenesis by the U87MG human glioma cell line. Asian Pac J Cancer Prev. 2014;15:8225-8.

27. Sehrawat A, Singh SV. Benzyl isothiocyanate inhibits epithelial-mesenchymal transition in cultured and xenografted human breast cancer cells. Cancer Prev Res (Phila). 2011;4:1107-17.

28. Wolf MA, Claudio PP. Benzyl isothiocyanate inhibits HNSCC cell migration and invasion, and sensitizes HNSCC cells to cisplatin. Nutr Cancer. 2014; 66:285-94.

29. Yan H, Zhu Y, Liu B, Wu H, Li Y, Wu X, et al. Mitogen-activated protein kinase mediates the apoptosis of highly metastatic human non-small cell lung cancer cells induced by isothiocyanates. Br J Nutr. 2011;106:1779-91.

30. Lin JF, Tsai TF, Liao PC, Lin YH, Lin YC, Chen HE, et al. Benzyl isothiocyanate induces protective autophagy in human prostate cancer cells via inhibition of mTOR signaling. Carcinogenesis. 2013; 34:406-14.

31. Boreddy SR, Pramanik KC, Srivastava SK. Pancreatic tumor suppression by benzyl isothiocyanate is associated with inhibition of PI3K/AKT/FOXO pathway. Clin Cancer Res. 2011;17:1784-95.

32. Kim SH, Singh SV. p53-Independent apoptosis by benzyl isothiocyanate in human breast cancer cells is mediated by suppression of XIAP expression. Cancer Prev Res (Phila). 2010;3:718-26.

33. Sahu RP, Zhang $R$, Batra $S$, Shi $Y$, Srivastava SK. Benzyl isothiocyanate-mediated generation of reactive oxygen species causes cell cycle arrest and induces apoptosis via activation of MAPK in human pancreatic cancer cells. Carcinogenesis. 2009; 30:1744-53.

34. Zhu M, Li W, Lu Y, Dong X, Chen Y, Lin B, et al. Alpha fetoprotein antagonized apoptosis induced by paclitaxel of hepatoma cells in vitro. Sci Rep. 2016; 6: 26472.

35. Zhu M, Lu Y, Li W, Guo J, Dong X, Lin B, et al. Hepatitis B virus X protein driven alpha fetoprotein expression to promote malignant behaviors of normal liver cells and hepatoma cells. J Cancer. 2016; 7:935-46.

36. Lee CS, Cho HJ, Jeong YJ, Shin JM, Park KK, Park YY, et al. Isothiocyanates inhibit the invasion and migration of C6 glioma cells by blocking FAK/JNK-mediated MMP-9 expression. Oncol Rep. 2015;34:2901-8.

37. Sakao K, Vyas AR, Chinni SR, Amjad AI, Parikh R, Singh SV. CXCR4 is a novel target of cancer chemopreventative isothiocyanates in prostate cancer cells. Cancer Prev Res (Phila). 2015; 8:365-74.

38. Hwang ES, Lee HJ. Benzyl isothiocyanate inhibits metalloproteinase-2/-9 expression by suppressing the mitogen-activated protein kinase in SK-Hep1 human hepatoma cells. Food Chem Toxicol. 2008;46:2358-64. 